\title{
AKTIVITAS PEMASARAN PRODUK BANK (STUDI KASUS: PADA PT. BANK PERKREDITAN RAKYAT BEROK GUNUNG PANGILUN PADANG)
}

\author{
Mariani St.B Tanjung \\ Akademi Keuangan dan Perbankan Padang \\ mstbtanjung@gmail.com
}

\begin{abstract}
ABSTRAK
Penelitian ini bertujuan untuk mengetahui bagaimana proses penghimpunan dana dan pemberian kredit serta aktivitas pemasaran produk bank pada PT. Bank Perkreditan Rakyat Berok Gunung Pangilun. Penelitian ini bersifat Deskriptif dengan menggunakan Analisa Kualitatif, dimana penelitian ini dilakukan dengan menganalisa dan menjelaskan proses penghimpunan dana masyarakat dan pemberian kredit, perkembangan penghimpunan dana masyarakat dan pemberian kredit, serta aktivitas pemasaran produk bank dalam meningkatkan penghimpunan dana dan pemberian kredit. prosedur untuk pemberian kredit, calon debitur harus mengajukan permohonan kredit kepada PT. BPR Berok Gunung Pangilun Padang dengan jaminan kredit berupa kendaraan, sertifikat tanah, hak sewa toko dan SK bagi PNS serta melengkapi dokumen lainnya. Bagi calon debitur yang memenuhi persyaratan, account officer akan mensurvey ke lapangan dan melakukan analisa terhadap prinsip $5 \mathrm{C}$ yang bertujuan untuk memutuskan apakah kredit tersebut ditolak atau disetujui. Apabila kredit disetujui maka pencarian kredit dapat dilakukan dengan membuka rekening tabungan pada PT. BPR Berok Gunung Pangilun Padang.
\end{abstract}

Kata Kunci: Aktivitas Pemasaran, Bank Perkreditan Rakyat

\section{PENDAHULUAN}

Perkembangan di sektor perbankan telah mendorong munculnya bankbank baru dan masuknya cabang-cabang bank asing di Indonesia, sehingga persaingan antar bank dalam memperebutkan pasar semakin ketat. Jika sebelumnya bank-bank tidak pernah melakukan kegiatan pemasaran, saat ini dipaksa harus melakukan pemasaran secara aktif dengan mendatangi calon nasabah baik di rumah maupun di tempat kerja yang disertai dengan promosi di media-media.

Pentingnya kegiatan pemasaran bank dilakukan dalam rangka memenuhi kebutuhan dan keinginan para nasabahnya terhadap produk dan jasa perbankan, baik produk simpanan (giro, tabungan, deposito), pinjaman (kredit) atau jasa-jasa bank lainnya. Penyediaan keinginan dan kebutuhan produk bank ini harus dilakukan melalui perencanaan yang matang, baik untuk perencanaan jangka pendek maupun jangka panjang. Dengan diketahuinya keinginan dan kebutuhan 
nasabah akan memudahkan bank untuk melakukan strategi guna merebut hati nasabah. Strategi yang dilakukan meliputi penentuan strategi produk, strategi harga, strategi lokasi dan strategi promosi. Strategi ini dikenal dengan nama bauran pemasaran (marketing mix).

Bank merupakan badan usaha yang tugas utamanya sebagai lembaga perantara keuangan (financial intermediaries), yang menyalurkan dana dari pihak yang berkelebihan dana kepada pihak yang membutuhkan dana atau kekurangan dana pada waktu yang ditentukan. Dana-dana bank yang digunakan sebagai alat bagi operasional suatu bank bersumber dari modal sendiri yang berasal dari pemilik bank, pinjaman dari pihak luar dan berupa simpanan dari pihak masyarakat (giro, tabungan, deposito). Sedangkan dana yang dihimpun oleh bank tersebut harus disalurkan kembali ke masyarakat dalam bentuk kredit. Karena pemberian kredit merupakan aktivitas bank yang paling utama dalam menghasilkan keuntungan, tetapi risiko yang terbesar dalam bank juga bersumber dari pemberian kredit. Oleh karena itu bank harus berhati-hati dalam menempatkan dana dalam bentuk kredit.

BPR sebagai salah satu bank yang ada dari perkembangan perbankan saat ini, dapat menghimpun dana dari masyarakat dalam bentuk tabungan dan deposito serta menyalurkan dana tersebut kembali dalam bentuk pemberian kredit pada masyarakat. Untuk itu BPR harus memasarkan produknya berdasarkan bauran pemasaran agar produk tersebut diminati oleh masyarakat. Karena keberhasilan suatu bank dalam menguasai pasar sangat tergantung pada pilihan suatu strategi dan kebijaksanaan serta aktivitas pemasaran yang lebih efektif.

Demikian juga halnya pada PT. BPR Berok Gunung Pangilun Padang mengantisipasi era globalisasi dan perdagangan bebas, mencoba memberikan inovasi dalam menghimpun dan menyalurkan dana kepada masyarakat lewat beragam produk - produk yang di pasarkan.

Berdasarkan uraian di atas, penulis tertarik dengan permasalahan pemasaran produk bank yang dilakukan oleh BPR, dengan melakukan penelitian yang berjudul "Aktivitas Pemasaran Produk Bank (Studi Kasus : Pada Pt. Bank Perkreditan Rakyat Berok Gunung Pangilun Padang).

Berdasarkan latar belakang diatas dapat dirumuskan masalah yang akan berpengaruh bagi kelangsungan hidup perusahaan, sehingga dapat dirumuskan masalahnya yaitu Bagaimana proses penghimpunan dana dan pemberian kredit serta aktivitas pemasaran produk bank pada PT. Bank Perkreditan Rakyat Berok Gunung Pangilun.

\section{METODE PENELITIAN}

\section{Teknik Pengumpulan Data}

Teknik pengumpulan data yang dilakukan penulis adalah riset perpustakaan dan riset lapangan.

1. Riset Perpustakaan (Library Research)

Riset ini dilakukan dengan mengumpulkan data dengan menggunakan teori-teori yang berkaitan dengan masalah-masalah yang akan dibahas, yang diperoleh dari literartur yang ada baik berupa buku-buku, majalahmajalah yang berkaitan dengan masalah yang akan diteliti. 


\section{Riset Lapangan (Field Research)}

Pada riset ini dilakukan dengan pengumpulan data-data dari PT. BPR Berok Gunug Pangilun Padang dengan melakukan wawancara langsung dengan pihak bank dan bersumber dari laporan keuangan tahunan yang telah diolah bank.

\section{Teknik Analisa}

Penelitian ini bersifat Deskriptif dengan menggunakan Analisa Kualitatif, dimana penelitian ini dilakukan dengan menganalisa dan menjelaskan proses penghimpunan dana masyarakat dan pemberian kredit, perkembangan penghimpunan dana masyarakat dan pemberian kredit, serta aktivitas pemasaran produk bank dalam meningkatkan penghimpunan dana dan pemberian kredit.

\section{LANDASAN TEORI \\ Pengertian Bank}

Bank merupakan suatu lembaga yang berperan sebagai perantara keuangan (Financial intermediary) antara pihak-pihak yang memiliki kelebihan dana dengan pihak-pihak yang memerlukan dana, serta sebagai lembaga yang berfungsi mempelancar lalu lintas pembayaran. Bank merupakan industri yang dalam kegiatannya mengandalkan kepercayaan masyarakat sehingga tingkat kesehatan bank perlu dijaga.

Pengertian Bank menurut Undang-undang RI No. 10 Tahun 1998 tentang perubahan undang-undang RI No. 7 Tahun 1992 Tentang Perbankan : " Bank adalah badan usaha yang menghimpun dana dari masyarakat dalam bentuk simpanan dan menyalurkannya kepada masyarakat dalam bentuk kredit dan atau bentuk-bentuk lainnya dalam rangka meningkatkan taraf hidup rakyat banyak"

Berdasarkan defenisi mengenai bank maka dapat dinyatakan fungsi bank adalah sebagai berikut :

a. Penghimpun dana masyarakat

b. Sebagai lembaga pemberi kredit

c. Sebagai lembaga yang melancarkan transaksi perdagangan dan pembayaran uang

\section{Pengertian Manajemen Pemasaran Bank}

Bagi dunia perbankan yang merupakan badan usaha yang berorientasi profil kegiatan pemasaran sudah merupakan suatu kebutuhan utama dan sudah merupakan suatu keharusan. Tanpa kegiatan pemasaran jangan diharapkan kebutuhan dan keinginan pelanggannya akan terpenuhi. Oleh karena itu bagi dunia perbankan perlu mengemas kegiatan pemasarannya secara terpadu dan terus menerus melakukan kegiatan riset pasar. Pemasaran harus dikelola secara profesional, sehingga kebutuhan dan keinginan pelanggan akan akan segera terpenuhi dan terpuaskan. Pengelolaan pemasaran bank yang profesional inilah yang kita sebut dengan manajemen pemasaran bank.

Secara umum pengertian manajemen pemasaran bank menurut Kasmir (2003 : 169) adalah : "Suatu proses perencanaan, pelaksanaan, pengendalian dari kegiatan menghimpun dana, menyalurkan dana, dan jasa-jasa keuangan 
lainnya dalam rangka memenuhi kebutuhan, keinginan, dan kepuasan nasabahnya".

Dari pengertian tersebut dapat diuraikan bahwa manajemen pemasaran bank merupakan usaha untuk memenuhi kebutuhan dan keinginan para nasabahnya terhadap produk dan jasa perbankan, baik produk simpanan (giro, tabungan dan deposito), pinjaman (kredit) atau jasa-jasa bank lainnya. Penyediaan keinginan dan kebutuhan produk bank ini harus dilakukan melalui perencanaan yang matang, baik perencanaan jangka pendek maupun jangka panjang. Selanjutnya dilaksanakan oleh bankir yang profesional. Kemudian perlu dilakukan pengawasan dan pengendalian terus-menerus agar tidak menyimpang dari yang sudah direncanakan. Pada akhirnya kegiatan pemasaran bank diharapkan dapat memenuhi kebutuhan dan keinginan nasabah serta tersebut juga akan memberikan kepuasan kepada para nasabahnya.

\section{Produk Bank}

Produk bank merupakan instrumen atau perangkat yang dibeli dan dijual oleh bank. Hal ini sesuai dengan fungsinya bahwa bank adalah lembaga keuangan dimana kegiatan sehari-harinya adalah dalam bidang jual beli uang. Tentu saja sebelum menjual uang (memberikan pinjaman) bank harus lebih dulu membeli uang (menghimpun dana) sehingga dari selisih bunga tersebutlah bank mencari keuntungan.

Produk yang dibeli oleh bank berada pada sisi pasiva yang merupakan penghimpun dana. Dana-dana yang termasuk produk bank (BPR) berasal dari masyarakat yaitu :

a. Tabungan

Menurut undang-undang RI No. 10 Tahun 1998 tentang perubahan undang-undang RI No. 7 Tahun 1992 tentang perbankan : "Tabungan adalah simpanan yang penarikannya hanya dapat dilakukan menurut syarat tertentu yang disepakati, tetapi tidak dapat ditarik dengan cek, bilyet giro, dan/atau alat lainnya yang dipersamakan dengan itu".

Secara umum tabungan merupakan salah satu kegiatan jasa perbankan yang diberikan kepada masyarakat yang membutuhkan jasa penyimpanan uang. Tabungan tersebut tidak memiliki ketetapan jangka waktu. Maksud penyimpanannya adalah untuk menabung, oleh sebab itu frekuensi pengambilannya sangat rendah. Setoran untuk tabungan umumnya juga dalam jumlah yang relatif kecil karena berasal dari sebagian pendapatan yang disisihkan untuk ditabung. Biasanya tabungan merupakan salah satu sarana promosi bagi pemerintah agar masyarakat melakukan penghematan dangan cara menabung, oleh karena itu penabung lebih banyak terdiri dari perorangan.

b. Deposito

Menurut undang-undang RI No. 10 Tahun 1998 tentang perubahan undang-undang RI No. 7 Tahun 1992 tentang Perbankan :

Deposito adalah simpanan penarikannya hanya dapat dilakukan pada waktu tertentu berdasarkan perjanjian nasabah penyimpan dengan bank.

Deposito dapat dibedakan sebagai berikut : 
1) Deposito Bejangka adalah deposito yang dibuat atas nama dan tidak dapat dipindah tangankan.

2) Sertifikat deposito adalah deposito yang diterbitkan atas unjuk dan dapat dipindah tangankan atau diperjual belikan, serta dapat dijadikan sebagai jaminan bagi permohonan kredit.

c. Kredit

Kredit merupakan produk yang dijual oleh bank dan berada pada sisi aktiva. Pemberian kredit merupakan salah satu bentuk usaha yang dapat dilakukan oleh sebuah bank dalam menyalurkan dananya kepada masyarakat. Dalam arti luas kredit diartikan sebagai kepercayaan. Begitu pula dalam bahasa latin kredit berarti “credere ” artinya percaya. Maksud dari percaya bagi sipemberi kredit adalah ia percaya kepada sipenerima kredit bahwa kredit yang disalurkannya pasti akan dikembalikan sesuai perjanjian.

Sedangkan bagi sipenerima kredit merupakan penerimaan kepercayaan sehingga mempunyai kewajiban untuk membayar sesuai jangka waktu.

Berdasarkan Undang-Undang RI No. 10 Tahun 1998 tentang perubahan Undang-Undang No. 7 tahun 1992 tentang perbankan, yang dimaksud dengan kredit :

"Penyediaan uang atau tagihan yang didapat dipersamakan dengan itu, berdasarkan persetujuan atau kesepakatan pinjam meminjam antara bank dengan pihak lain yang mewajibkan pihak meminjam untuk melunasi utangnya setelah jangka waktu tertentu dengan pemberian bunga ".

Adapun unsur yang terkandung dalam suatu pemberian fasilitas kredit menurut Kasmir (2003 : 94), dimana mencakup lima unsur yaitu :

1) Kepercayaan, yaitu suatu keyakinan pemberi kredit bahwa kredit yang akan diberikan akan benar-benar diterima kembali dimasa tertentu dimasa datang. Kepercayaan ini diberikan oleh bank, dimana sebelumnya sudah dilakukan penelitian penyelidikan tentang nasabah baik secara intern maupun eksteren. Penelitian dan penyelidikan tentang kondisi masa lalu dan sekarang terhadap nasabah pemohon kredit.

2) Kesepakatan, disamping unsur percaya didalam kredit juga mengandung unsur kesepakatan antara sipemberi kredit dengan sipenerima kredit. Kesepakatan ini dituangkan dalam suatu perjanjian dimana masing-masing pihak menandatangani hak dan kewajibannya masing-masing.

3) Jangka waktu, setiap kredit yang diberikan memiliki jangka waktu tertentu, jangka waktu ini mencakup masa pengembalian kredit yang telah disepakati. Jangka waktu tersebut bisa berbentuk jangka pendek, jangka menengah atau jangka panjang.

4) Resiko, adanya suatu tenggang waktu pengembalian akan menyebabkan suatu resiko tidak tertagihnya atau macet pemberian kredit. Semakin panjang suatu kredit semakin besar resikonya demikian pula sebaliknya. Resiko ini menjadi tanggungan bank, baik 
resiko yang disengaja oleh nasabah yang lalai, maupun oleh resiko yang tidak disengaja.

5) Balas jasa, merupakan keuntungan atas pemberian suatu kredit atau jasa tersebut yang kita kenal dengan nama bunga. Balas jasa dalam bentuk bunga dan biaya administrasi kredit ini merupakan keuntungan bank. Sedangkan bagi bank yang berdasarkan prinsip syariah balas jasanya ditentukan dengan bagi hasil.

\section{Bauran Pemasaran}

Bauran pemasaran (Marketing Mix) merupakan kegiatan pemasaran yang dilakukan secara terpadu. Artinya kegiatan ini dilakukan secara bersamaan diantara elemen-elemen yang ada dalam marketing mix itu sendiri. Setiap elemen tidak dapat berjalan sendiri-sendiri tanpa dukungan dari elemen yang lain. Oleh karena itu setiap elemen membutuhkan strategi tersendiri, namun tetap akan terkait dengan strategi pada elemen lainnya.

Elemen-elemen yang ada dalam marketing mix adalah :

a. Strategi Produk (Product)

Produk secara umum diartikan sebagai suatu yang dapat memenuhi kebutuhan dan keinginan pelanggan. Artinya apapun wujudnya, selama itu dapat memenuhi keinginan pelanggan dan kebutuhan kita katakan sebagai produk.

Menurut Simorangkir (1992) yang dikutip Dendrawijaya (2001 : 72), produk perbankan adalah instrumen atau perangkat yang dibeli dan dijual oleh bank. Produk yang dibeli dan dijual oeh bank sangat banyak jumlahnya, karena bank dapat menciptakan berbagai jenis produk sesuai dengan keinginan dan kebutuhan nasabah.

Produk yang diinginkan pelanggan adalah produk yang berkualitas tinggi. Artinya produk yang ditawarkan oleh bank ke nasabahnya memiliki nilai yang lebih baik dibandingkan dengan produk pesaing. Selain itu, kelengkapan jenis produk bank yang ditawarkan sangat tergantung dari kemampuan bank itu sendiri. Semakin lengkap produk yang ditawarkan akan semakin baik sehingga untuk memperoleh produk bank nasabah cukup mendatangi satu bank saja.

Dalam starategi produk bank harus dapat memodifikasi produk yang sudah ada menjadi lebih menarik. Atau bank pun dapat menciptakan produk baru. Strategi produk biasanya dimulai dari penciptaan logo dan moto yang dibuat semenarik mungkin. Kemudian menciptakan merek terhadap produk yang ditawarkan.

b. Strategi Harga (Price)

Harga salah satu aspek penting dalam kegiatan marketing mix. Penentuan harga menjadi sangat penting untuk diperhatikan, mengingat harga sangat menentukan laku tidaknya produk dan jasa perbankan. Salah satu dalam menentukan harga akan berakibat fatal terhadap produk yang ditawarkan. Dalam perbankan penetapan harga adalah penetapan tingkat suku bunga yang terdiri dari bunga simpanan dan bunga kredit. Bunga simpanan merupakan biaya dana yang harus dikeluakan kepada nasabah sedangkan pinjaman merupakan pendapatan yang diterima dari nasabah. 
Penentuan harga oleh suatu bank dimaksudkan untuk berbagai tujuan yang hendak dicapai. Secara umum tujuan penentuan harga adalah sebagai berikut (Kasmir, $2003: 198$ ) :

1) Untuk bertahan hidup

Dalam hal ini bank menentukan harga semurah mungkin dengan maksud produk atau jasa yang ditawarkan laku pasaran.

2) Untuk memaksimalkan laba

Tujuan harga ini dengan mengharapkan penjualan yang meningkat sehingga laba dapat ditingkatkan. Penentuan harga biasanya dapat dilakukan dengan harga murah atau tinggi.

3) Untuk memperbesar market share

Penentuan harga ini dengan harga yang murah sehingga diharapkan jumlah pelanggan meningkat dan diharapkan pula pelanggan pesaing beralih ke produk yang ditawarkan seperti pentuan suku bunga simpanan yang lebih tinggi dari pesaing.

4) Mutu Produk

Tujuannya adalah untuk memberikan kesan bahwa produk atau jasa yang ditawarkan memiliki kualitas yang tinggi dan biasanya harga jual ditentukan setinggi mungkin.

\section{5) Karena Pesaing}

Dalam hal ini penentuan harga dengan melihat harga pesaing. Tujuannya adalah agar harga yang ditawarkan jangan melebihi harga pesaing artinya bunga simpanan di atas pesaing dan bunga pinjaman dibawah pesaing.

c. Strategi Lokasi (Place)

Penentuan lokasi bagi industri perbankan lebih ditekankan kepada lokasi cabang. Penentuan lokasi kantor cabang bank dilakukan untuk cabang utama, cabang pembantu atau kantor kas. Penentuan lokasi kantor beserta sarana dan prasarana pendukung menjadi sangat penting, hal ini disebabkan agar nasabah mudah menjangkau lokasi bank yang ada. Demikian pula sarana dan prasarana harus memberikan rasa yang nyaman dan aman kepada seluruh nasabah yang berhubungan dengan bank.

Pemilihan lokasi sangat penting mengingat apabila salah dalam menganalisis akan berakibat meningkatnya biaya yang akan dikeluarkan nantinya. Lokasi yang tidak strategis akan mengurangi minat nasabah untuk berhubungan dengan bank.

d. Strategi promosi (Promotion)

Promosi merupakan kegiatan marketing mix yang terakhir. Kegiatan ini merupakan kegiatan yang sama pentingnya dengan ketiga kegiatan diatas, baik produk, harga, dan lokasi. Dalam kegiatan ini setiap bank berusaha untuk mempromosikan seluruh produk dan jasa yang dimilikinya baik langsung maupun tidak langsung.

Tanpa promosi jangan diharapkan nasabah dapat mengenal bank. Oleh karena itu promosi merupakan sarana yang paling ampuh untuk menarik dan mempertahankan nasabahnya. Salah satu tujuan promosi bank 
adalah menginformasikan segala jenis produk yang ditawarkan dan berusaha menarik calon nasabahnya yang baru.

Kasmir (2003 : 213) me2nyatakan bahwa ada empat macam sarana promosi yang dapat digunakan oleh setiap bank dalam mempromosikan baik produk maupun jasanya yaitu :

1) Periklanan (Advertising)

Iklan adalah sarana promosi yang digunakan oleh bank guna menginformasikan, menarik dan mempengaruhi calon nasabahnya. Penggunaan promosi dengan iklan dapat dilakukan dengan berbagai media seperti koran, majalah, televisi, radio, atau media lainnya.

2) Promosi penjualan (Sales Promotion)

Tujuan promosi penjualan adalah untuk meningkatkan penjualan atau untuk meningkatkan jumlah nasabah. Promosi penjualan dilakukan untuk menarik nasabah untuk segera membeli setiap produk atau jasa yang ditawarkan. Oleh karena itu agar nasabah tertarik untuk membeli maka perlu dibuatkan promosi penjualan yang semenarik mungkin.

3) Publisitas (Publicity)

Publisitas merupakan kegiatan promosi untuk memancing nasabah melalui berbagai media. Kegiatan ini dapat menigkatkan pamor bank dimata para nasabahnya, baik secara langsung atau tidak langsung.

4) Penjualan Pribadi (Personel Selling)

Dalam dunia perbankan penjualan pribadi secara umum dilakukan oleh seluruh pegawai bank, mulai dari cleaning service, satpam sampai pejabat bank. Secara khusus Personal Selling dilakukan oleh petugas Customer Service atau Service Assistensi.

\section{HASIL PENELITIAN}

\section{Proses Pemasaran Produk PT. BPR Berok Gunung Pangilun Padang}

Menurut Siamat (1993:84), dana bank adalah uang tunai yang dimilki bank ataupun aktiva lancar yang dikuasai bank dan setiap waktu dapat diuangkan. Uang tunai yang dimiliki bank tidak hanya berasal dari modal bank itu sendiri, tetapi juga berasal dari pihak lain yang dititipkan atau dipercayakan pada bank yang sewaktu-waktu akan diambil kembali, baik sekaligus maupun secara berangsur-angsur.

Dana dari masyarakat merupakan sumber dana yang paling besar yang dapat dihimpun melalui produk-produk yang ditawarkan oleh PT. BPR Berok Gunung Pangilun Padang. Sehingga dalam menghimpun produkproduk tersebut PT. BPR Berok Gunung Pangilun Padang perlu melakukan kegiatan pemasaran produk kepada masyarakat, dengan harapan PT. BPR Berok Gunung Pangilun Padang dapat menarik minat calon nasabah yang baru atau dapat mempertahankan nasabah yang suadah ada sekarang ini.

PT. BPR Berok Gunung Pangilun Padang harus meningkatkan mutu pelayanan dan menyediakan ragam produk yang sesuai dengan keinginan dan kebutuhan nasabah. Sehingga nasabah merupakan manfaat dan keuntungan yang diperoleh dari produk-produk tersebut. Produk-produk yang ada pada PT. BPR Berok Gunung Pangilun Padang antara lain berupa : 
a. Tabungan

1) Simanis Berok Gunung Pangilun

Tabungan Simanis Berok Gunung Pangilun merupakan salah satu jenis tabungan yang ada pada PT. BPR Berok Gunung Pangilun Padang. Fasilitas yang dapat diperoleh oleh nasabah adalah :

a) Bunga menarik

b) Pengambilan dan penyetoran dapat dilakukan kapan saja.

c) Gratis asuransi jiwa Askrida.

Persyaratan membuka rekening Simanis BGP :

a) Menyerahkan photocopy KTP/SIM.

b) Mengisi permohonan pembukaan tabungan Simanis BGP.

c) Setoran awal minimal Rp. 25.000,-

2) Simpanan Bajapuik

Tabungan Simpanan Bajapuik merupakan salah satu jenis tabungan PT. BPR Berok Gunung Pangilun Padang yang dilakukan dalam sistem jemput bola atau mendatangi nasabah.

Fasilitas yang dapat diperoleh adalah :

a) Bunga menarik

b) Penyetoran dijemput ke tempat nasabah

c) Setoran awal minimal Rp. 25.000,-

Prosedur pembukaan rekening tabungan PT. BPR Berok Gunung Pangilun Padang :

1) Calon nasabah datang menghadap petugas dna menyatakan maksudnya untuk membuka rekening tabungan baru.

2) Petugas menjelaskan bentuk tabungan yang ada berikut dengan persyaratannya dan selanjutnya minta persetujuan calon nasabah (jika setuju nasabah diminta untuk mengisi permohonan yang telah disediakan PBR dan menyerahkan kartu identitasnya untuk dicatat nantinya pada speciment).

3) Calon nasabah menyatakan persetujuannya, mengisi blanko permohonan dan menyerahkan kartu identitasnya kepada petugas untuk dicatat.

4) Petugas memeriksa pengisian blanko permohonan dan keabsyahan kartu identitas nasabah. Selanjutnya mempersiapkan dan meminta nasabah untuk mencantumkan contoh tanda tangannya pada speciment.

5) Nasabah mencantumkan contoh tanda tangannya pada blanko speciment dan menyerahkannya kembali kepada petugas.

6) Petugas memeriksa pencantuman tanda tangan nasabah yang bersangkutan dan mencatatkan data kartu identitas nasabah yang bersangkutan pada blanko speciment tersebut, menyiapkan nomor rekening dan buku tabungan baru untuk nasabah yang bersangkutan dan minta nasabah menyetorkan setoran awalnya melalui kasir dengan menggunakan slip setoran.

7) Nasabah menyetorkan setoran awalnya melalui kasir, dengan menggunakan slip penyetoran. 
8) Kasir menerima setoran dari nasabah sejumlah yang tercantum pada slip setoran, mencantumkan parafnya pada slip setoran dimaksud dan kemudian menyerahkan kembali slip setoran itu kepada petugas.

9) Petugas mencatatkan setoran nasabah tersebut pada buku tabungan dan rekening tabungan melalui program /aplikasi komputer dan kemudian setelah memarafnya menyerahkan berkas pembukaan tabungan baru ini (permohonan, kartu identitas nasabah, speciment, buku tabungan dan slip setoran) kepada pejabat untuk minta persetujuan.

10) Pejabat mengamati dan memeriksa semua berkas diatas dan jika O.K. langsung memberikan persetujuan, dengan mencantumkan tanda tangannya pada speciment dan permohonan nasabah. Kemudian menyerahkan kembali berkas dimaksud kepada petugas.

11) Petugas menyerahkan buku tabungan dan kartu identitas tadi kepada nasabah/penabung, menyimpan berkas tabungan baru dan mengumpulkan slip setoran untuk nantinya direkap dan dijilid sebagai bukti pembukuan pada hari yang sama.

b. Deposito Berjangka Berok Gunung Pangilun

Deposito berjangka berok gunung pangilun adalah simpanan yang penarikannya d ilakukan dalam jangka waktu tertentu.

Fasilitas yang dapat diperoleh adalah :

1) Deposito dalam rupiah

2) Bunga deposito bersaing

3) Bunga dapat diambil setiap bulan atau dipindah bukukan ke rekening tabungan.

4) Jangka waktu dapat dipilih antara 1 bulan, 3 bulan, 6 bulan, 12 bulan dan 24 bulan dan dapat diperpanjang secara otomatis.

Persyaratan pembukaan deposito berjangka berok gunung pangilun :

1) Mengisi permohonan

2) Menyerahkan photocopy KTP/SIM

Prosedur pembukaan rekening deposito PT. BPR Berok Gunung Pangilun Padang :

1) Nasabah datang menemui petugas dan menyampaikan maksudnya untuk membuka deposito baru.

2) Petugas menjelaskan ketentuan dan syarat-syarat pembukaan deposito yang ada dan minta nasabah untuk menentukan pilihannya serta mengisi dan menandatangani blanko permohonan.

3) Nasabah setuju dan menentukan pilihannya. Selanjutnya mengisi dan menada tangani blanko permohonan dan menyerahkannya kembali kepada petugas.

4) Petugas meneliti pengisian blanko permohonan dan jika O.K minta nasabah menandatangani speciment dan menyerahkan kartu identitasnya untuk dicatat pada speciment tersebut.

5) Nasabah menandatangani blanko speciment dan menyerahkannya kembali kepada petugas beserta dengan kartu identitasnya. 
6) Petugas mencatatkan kartu identitas nasabah yang bersangkutan pada speciment, menyiapkan bilyet deposito dan minta nasabah menyetorkan uang depositonya kepada kasir.

7) Nasabah menyetorkan uang depositonya kepada kasir.

8) Kasir menghitung uang setoran dan mencocokkan jumlahnya dengan slip setoran dan nominal deposito pada bilyet jika cocok mencantumkan parafnya pada slip dan bilyet deposito. Menyerahkan kembali bilyet itu berikut slip setoran kepada petugas.

9) Petugas :

a) Mencatat pembukaan deposito ini pada buku register deposito dan aplikasi/program komputer, sesuai dengan menunya.

b) Setelah itu menyerahkan berkas deposito dimaksud yang berisikan, permohonan, speciment, kartu identitas nasabah, slip setoran dan bilyet deposito, kepada pejabat yang berwenang untuk diberikan persetujuan.

10) Pejabat yang berwenang memeriksa keabsyahan dan pemenuhan persyaratan formal pembukaan deposito baru dan jika sudah O.K langsung menanda tangani bilyet a.n BPR dan menyerahkan berkas itu kembali kepada petugas.

11) Petugas menyerahkan asli bilyet deposito dan kartu identitas kepada nasabah, menyimpan lembar kedua bilyet untuk bukti pembukuan dan lembar ketiga untuk arsip.

c. Kredit

Perkembangan simpanan masyarakat yang disimpan oleh perbankan salah satu elemen penting untuk pembiayaan pembangunan, dimana simpanan masyarakat tersebut akan disalurkan menjadi investasi melalui penyediaan dana berupa kredit perbankan. Adapun macam-macam bentuk produk kredit yang disalurkan pada PT. BPR Berok Gunung Pangilun Padang adalah :

1) Kredit Investasi

Yaitu pinjaman yang diberikan untuk keperluan pembelian barangbarang modal dan jasa yang diperlukan guna rehabilitasi, modernisasi, ekspansi, realokasi usaha atau pendirian usaha baru.

2) Kredit Modal Kerja

Yaitu pinjaman yang diberikan untuk kepentingan modal kerja debitur/nasabah yang bersangkutan.

3) Kredit Konsumsi

Yaitu kredit yang diberikan untuk keperluan konsumsi berupa barang-barang atau jasa yang dibeli, menyewa ataupun dengan cara lain. Biasanya ini khusus untuk pegawai.

Calon debitur yang ingin mendapatkan kredit, terlebih dahulu harus mengajukan permohonan kepada pihak PT. BPR Berok Gunung Pangilun Padang. Adapun prosedur pemberian kredit pada PT. BPR Berok Gunung Pangilun Padang sebagai berikut :

1. Calon debitur mengajukan permohonan kredit kepada PT. BPR Berok Gunung Pangilun Padang dengan persyaratan yang dipenuhi oleh : 
Peryaratan Umum :

a. Mempunyai jaminan kredit berupa :

a. Kendaraan bermotor roda dua (minimal tahun buatan 1995)

b. Kendaraan bermotor roda empat (minimal tahun buatan 1990)

c. Sertifikat tanah hak milik

d. Hak sewa toko pada Pemda

e. SK bagi Pegawai Negeri Sipil

b. Mempunyai usaha yang sedang berjalan (minimal 6 bulan), syarat ini ditujukan untuk kredit investasi dan kredit modal kerja.

Kelengkapan dokumen : (bagi jaminan kendaraan)

a. Foto copy KTP suami /istri (rangkap 2)

b. Foto copy Kartu Keluarga (rangkap 2)

c. Foto copy rekening air / listrik / telepon (rangkap 1)

d. Foto copy STNK yang masih berlaku (rangkap 2)

e. Foto copy BPKB (rangkap 1)

f. Kwitansi pembelian kendaraan (bagi kendaraan yang belum balik nama)

g. Kwitansi kosong pembelian kendaraan pakai materai.

h. Surat keterangan usaha dari kelurahan / SIUP.

i. Cek fisik kendaraan (No. rangka /No. Mesin)

j. Pas foto pemohon $3 \times 4=1$ lembar.

Kelengkapan Dokumen : (bagi jaminan sertifikat tanah)

a. Foto copy KTP suami /istri (rangkap 2)

b. Foto copy Kartu Keluarga (rangkap 2)

c. Foto copy rekening air / listrik / telepon (rangkap 1)

d. Foto copy sertifikat tanah (rangkap 2)

e. Foto copy akta jual beli (rangkap 1)

f. Bukti pembayaran PBB terakhir

g. Surat keterangan usaha dari Kelurahan / SIUP

h. Pas foto pemohon $3 \times 4=1$ lembar

Persyaratan lain :

a. Bagi jaminan berupa kendaraan pembayaran pajak kendaraan harus SAMSAT Padang.

b. Seluruh berkas dimasukkan dalam map tersendiri.

2. Bank mencatat permohonan kredit ke dalam buku register dan meneliti surat permohonan kredit beserta kebenaran dokumen-dokumen yang diserahkan calon debitur.

3. Account Officer melakukan kegiatan pencarian informasi selengkaplengkapnya dari berbagai sumber mengenai calon debitur. Informasi tersebut dapat diperoleh melalui wawancara dengan calon debitur, kunjungan ke lokasi calon debitur dan penyelidikan tentang tujuan penggunaan kredit.

4. Melakukan analisa dan evaluasi terhadap Prinsip $5 \mathrm{C}$ calon debitur, yaitu : 
a. Watak (Character)

Bertujuan untuk mendapatkan gambaran akan perilaku calon debitur sebelum dan selama permohonan kredit diajukan. Prinsip-prinsip yang digunakan dalam menilai kejujuran, ketulusan dan kemauan untuk membayar kembali hutangnya, karena hal ini akan menunjukkan bahwa calon debitur dapat dipercaya dalam kaitannya dengan pengembalian kredit.

b. Kemampuan (Capacity)

Merupakan gambaran mengenai kemampuan calon debitur untuk memenuhi kewajiban-kewajibannya. Dalam menganalisa capacity ini PT. BPR Berok Gunung Pangilun Padang akan melihat kemampuan calon debitur dari usaha yang dibiayai mencakup aspek manajemen (kemampuan mengelola perusahaan), aspek produksi (kemampuan berproduksi secara berkesinambungan), aspek pemasaran (kemampuan memasarkan hasil produksi), aspek personalia (kemampuan tenaga kerja dalam mendukung aktivitas perusahaan), dan aspek finansial (kemampuan menghasilkan laba).

c. Modal (Capital)

Bertujuan untuk mengukur kemampuan calon debitur dalam menyediakan modal sendiri. Dalam hal ini PT. BPR Berok Gunung Pangilun Padang mensyaratkan 10\% modal sendiri dari keseluruhan dana yang dibutuhkan.

d. Kondisi Ekonomi (Condition of Economic)

Dalam menganalisa Conditions of Economic PT. BPR Berok Gunung Pangilun Padang akan melihat kondisi perusahaan sekarang maupun yang akan datang sesuai dengan perkembangan usaha, jenis usaha yang dilaksanakan.

e. Agunan (Collateral)

Menyangkut nilai harta yang dijamin oleh calon debitur sebagai jaminan atau kredit yang diajukan PT. BPR Berok Gunung Pangilun Padang mensyaratkan kepada calon debitur untuk menyediakan jaminan sebesar $60 \%$ dari jumlah kredit yang diajukan. Adapun bentuk jaminan dapat berupa sertifikat tanah, mobil/kendaraan bermotor dan hak sewa toko.

5. Rekomendasi kredit oleh Account Officer secara tertulis. Isi rekomendasi tersebut adalah :

a. Tujuan penggunaan kredit

Penggunaan kredit harus sesuai dengan bidang usaha debitur, berdasarkan target produktifitas yang akan dicapainya. Adapun pemberian kredit pada PT. BPR Berok Gunung Pangilun Padang digunakan untuk membiayai usaha debitur dalam sektor pertanian, perindustrian, perdagangan dan jasa lainnya.

b. Plafond kredit

Jumlah kredit yang diberikan PT. BPR Berok Gunung Pangilun Padang kepada debitur yang menerima kredit. 
c. Jangka Waktu

Jangka waktu kredit yang diberikan oleh PT. BPR Berok Gunung Pangilun Padang paling lama 3 tahun.

d. Jenis kredit yang diajukan Jenis-jenis kredit pada PT. BPR Berok Gunung Pangilun Padang adalah kredit investasi, kredit modal kerja dan kredit konsumsi.

e. Bunga yang harus dibayar

Ketentuan bunga pada PT. BPR Berok Gunung Pangilun Padang :

1) Cara Penghitungan

a) Bunga flat yaitu bunga yang berdasarkan pada limit selama jangka waktu kredit.

b) Bunga anuitas yaitu perhitungan yang didasarkan pada bukti debet harian dan bearnya angsuran per bulan (pokok dan bunga)

c) Bunga efektif yaitu perhitungan bunga yang didasarkan pada bukti debet harian dikalikan dengan bunga yang berlaku.

2) Hari Bunga

Hari bunga dihitung 30 hari dalam sebulan atau 360 hari dalam setahun

3) Jenis Bunga

a) Fixed rate yaitu suku bunga yang dikenakan secara tetap selama jangka waktu kredit.

b) Floating rate yaitu suku bunga yang dikenakan secara mengambang artinya sewaktu-waktu dapat berubah sesuai perkembangan bunga yang berlaku dipasaran.

f. Provisi kredit

Merupakan suatu beban yang dikenakan kepada debitur sebagai akibat dari perjanjian kredit yang dibuat.

g. Agunan

Agunan harus dikemukakan secara terperinci, seperti jumlah jaminan, nilai jaminan dan status pemiliknya. Adapun bentuk jaminan dapat berupa sertifikat tanah, mobil/kendaraan bermotor dan hak sewa toko.

h. Asuransi lainnya

Setiap pemberian kredit kepada debitur selalu diasuransikan, hal ini dimaksudkan untuk mengamankan resiko bilamana terjadi hal-hal yang tidak diinginkan.

i. Administrasi lainnya

6. Keputusan terhadap persetujuan kredit di PT. BPR Berok Gunung Pangilun Padang berada ditangan Direksi dengan memperhatikan rekomendasi dari Account Officer dan analisa bagian pemasaran dan penilaian kredit.

7. Setelah kredit disetujui pihak PT. BPR Berok Gunung Pangilun, PT. BPR Berok Gunung Pangilun Padang menyuruh debitur untuk menandatangani surat Persetujuan Membuka Kredit (PMK), Surat kuasa, surat penyerahan hak milik atas dasar kepercayaan (FEO), kwitansi 
penarikan kredit, kartu cicilan kredit dan lain-lain oleh bagian kredit. Apabila kredit tidak disetujui maka akan diberitahukan kepada nasabah.

8. Pencairan kredit dapat dilakukan dengan membuka rekening tabungan pada PT. BPR Berok Gunung Pangilun dan PT. BPR Berok Gunung Pangilun Padang dapat melakukan pendebetan ke rekening tabungan debitur.

\section{Perkembangan Jumlah Dana Masyarakat pada PT. BPR Berok Gunung Pangilun Padang}

Bank bertugas memberikan pelayanan kepada masyarakat dan bertindak selaku perantara bagi keuangan masyarakat. Oleh karena itu, bank harus selalu berada ditengah masyarakat agar arus uang dari masyarakat yang kelebihan dana dapat ditampung dan disalurkan kembali kepada masyarakat yang kekurangan dana. Dana dari masyarakat yaitu dana yang berasal dari luar bank yang dipercayakan oleh masyarakat atau nasabah yang sewaktu-waktu dapat ditarik.

Pada PT. BPR Perkreditan Rakyat Berok Gunung Pangilun Padang sumber dana dari masyarakat hanya berupa deposito dan tabungan. Untuk mengetahui sejauh mana dana masyarakat yang diperoleh oleh PT. BPR Berok Gunung Pangilun Padang dapat dilihat pada tabel 1 dibawah ini :

\section{Tabel 1}

Perkembangan Penghimpunan Dana Masyarakat

PT. BPR Berok Gunung Pangilun Padang

Per 31 Desember 2009 - 31 Desember 2010

(Dalam Ribuan Rupiah)

\begin{tabular}{|c|c|c|c|c|}
\hline Uraian & $\begin{array}{c}\text { Posisi Desember } \\
\text { 2009 }\end{array}$ & $\begin{array}{c}\text { Posisi Desember } \\
\mathbf{2 0 1 0}\end{array}$ & $\begin{array}{c}\text { Naik/ } \\
\text { Turun }\end{array}$ & Persentase \\
\hline Tabungan & 3.929 .481 & 4.832 .234 & 90.2753 & 22,97 \\
Deposito & 14.069 .150 & 15.280 .950 & 1.211 .800 & 8,61 \\
Jumlah & 17.988 .631 & 20.113 .184 & 2.114 .553 & 11.75 \\
\hline
\end{tabular}

Sumber : PT. BPR Berok Gunung Pangilun Padang

Dari tabel diatas dapat diketahui posisi dana pada akhir Desember 2010 adalah sebesar Rp. 20.113.184.000,- meningkat sebesar Rp. 2.114.553.000,- atau $11,75 \%$ dari posisi akhir Desember 2009 yaitu sebesar Rp. 17.998.631.000,- atau $22,97 \%$ pada tahun 2010. Sedangkan jumlah deposito juga mengalami peningkatan sebesar Rp. 1.211.800.000,- atau 8,61\% pada tahun 2010

Peningkatan penghimpunan dana ini adalah di sebabkan karena tingginya kepercayaan masayarakat kepada PT. BPR Berok Gunug Pangilun Padang sehingga mau menyimpan dananya dalam bentuk tabunga dan deposito.

Perkembangan Jumlah Kredit Pada PT. BPR Berok Gunung Pangilun Padang.

Kegiatan bank yang kedua setelah menghimpun dana dari masyarakat adalah menyalurkan kembali dana tersebut kepada masyarakat yang membutuhkannya. Kegiatan penyaluran dana ini dikenal dengan pemberian kredit. Pemberian kredit merupakan tulang punggung kegiatan perbankan, yang bertujuan agar bank dapat memperoleh keuntungan seoptimal mungkin. Sehingga melalui kredit, bank akan menambah dananya sendiri. 
Adapun macam kredit yang diberikan oleh PT. BPR Berok Gunung Pangilun adalah kredit investasi, kredit modal kerja dan kredit konsumsi. Untuk dapat melihat perkembangan jumlah kredit yang diberikan oleh PT. BPR Berok Gunung Pangilun setiap tahunnya dapat dilihat pada tabel 3.2 dibawah ini :

Tabel 2

Perkembangan Jumlah Kredit Yang Disalurkan

PT. BPR Berok Gunung Pangilun Padang

Tahun 2006-2010

(Dalam Ribuan Rupiah)

\begin{tabular}{|c|c|c|}
\hline Tahun & Jumlah Kredit & $\begin{array}{c}\text { Pertumbuhan } \\
(\boldsymbol{\%})\end{array}$ \\
\hline 2006 & 6.667 .208 & - \\
2007 & 13.500 .745 & 102 \\
2008 & 16.427 .220 & 22 \\
2009 & 17.923 .866 & 9 \\
2010 & 22.854 .628 & 28 \\
\hline
\end{tabular}

Sumber : PT. BPR Berok Gunung Pangilun Padang

Dari tabel 2 diatas dapat dilihat perkembangan jumlah kredit yang disalurkan olel PT. BPR Berok Gunung Pangilun mengalami peningkatan yang cukup berarti, hal ini terlihat dari kenaikan jumlah kredit yang disalurkan meningkat pada tahun 2007 dengan jumlah Rp. 13.500.745.000,- dengan pertumbuhan sebesar $102 \%$ dan pada tahun 2008 meningkat sebesar $22 \%$. Begitu pula pada tahun 2009 memperlihatkan pertumbuhan jumlah redit yang disalurkan sebesar 9\% walaupun penigkatan ini tidak sebesar pada tahun 2007 tetapi jumlah kredit yang disalurkan kepada masyarakat tetap menigkat, begitu pula tahun 2010 menigkat sebesar 28\%. Dilihat secara umum maka dari tahun ketahun jumlah kredit selalu mengalami peningkatan dan pertumbuhan terbesar terjadi pada tahun 2007 yaitu sebesar 102\% dengan jumlah kredit sebesar Rp. 13.500.745.000,-. Sedangkan rata-rata peningkatan sebesar 32,20\% setiap tahunnya selama lima tahun terakhir.

\section{Aktivitas Pemasaran Produk Yang Dilakukan PT. BPR Berok Gunung Pangilun Padang}

Kegiatan pemasaran sudah merupakan kebutuhan utama dan suatu keharusan bagi dunia perbankan dalam mempertahankan kelangsunagn hidupnya, sehingga berkembang dan mendapatkan laba. Pentingnya pemasaran dilakukan dalam rangka memenuhi kebutuhan dan keinginnan masyarakat akan suatu produk atau jasa. Pemasaran menjadi semakin penting dilakukan dalam rangka menghadapi pesaing yang dari waktu ke waktu semakin menigkat. Berhasil tidaknya dalam pencapaian tujuan perusahaan tergantung pada pengelolaan yang dilakukan secara profesional sehingga kebutuhan dan keinginan pelanggan akan segera terpenuhi.

Oleh sebab itu, diperlukan suatu aktivitas pemasaran produk yang dapat menunjang peningkatan jumlah nasabah pada PT. BPR Berok Gunung Pangilun, yaitu sebagai berikut : 
a. Strategi Produk

Produk yang diinginkan pelanggan adalah produk yang berkualitas tinggi, sehingga bank dituntut agar dapat memodifikasi produk yang sudah ada menjadi lebih menarik. Dalam hal ini PT. BPR Berok Gunung Pangilun telah melakukan berbagai strategi produk agar dapat memiliki keunggulan yang lebih jika dibandingkan dengan produk bank pesaing PT. BPR Berok Gunung Pangilun telah menciptakan sendiri produk tabungan seperti Simanis BGP Simpanan Bajapuik. Ini bertujuan untuk memuaskan keinginan penabungnya sehingga penabung tersebut merasakan manfaat dan keuntungan jika memakai produk tersebut.

Salah satu strategi produk adalah memberikan nama terhadap produk yang dihasilkannya. Merek bukan saja merupakan tanda atau identitas dari produk suatu bank, tapi sekaligus menggambarkan reputasi dan kualitas perusahaan. Sehingga dengan menyebut nama atau merek suatu produk maka orang akan langsung mengingat perusahaan yang menciptakan atau memasarkan produk tersebut. Misalnya dengan menyebut Simanis BGP , maka orang akan mengingat bahwa itu adalah produk tabungan dari PT. BPR Berok Gunung Pangilun.

b. Startegi Harga

Keuntungan utama dari bisnis perbankan adalah bagaimana mengelola dan menentukan bunga pinjaman secara fleksibel sehingga menghasilkan laba yang maksimal. Artinya tingkat suku bunga pinjman haruslah lebih tinggi dari suku bunga simpanan sehingga bank memperoleh keuntungan. PT. BPR Berok Gunung Pangilun menetukan tingkat bunga tergantung kepada jenis produk simpanan. Tingkat bunga ditentukan sendiri oleh PT. BPR Berok Gunung Pangilun yaitu dengan tingkat bunga pasar dan berdasarkan jumlah saldo yang dimliki nasabah.

Dalam menentukan besar kecilnya suku bunga kredit yang akan diberikan kepada para debitur terdapat beberapa komponen yang perlu diperhatikan oleh PT. BPR Berok Gunung Pangilun, yaitu :

1) Total biaya dana

Merupakan total bunga kredit yang dikeluarkan oleh bank untuk memperoleh dana simpanan dalam bentuk tabungan dan deposito. Total biaya dana tergantung dari seberapa besar bunga yang ditetapkan untuk memperoleh dana yang diinginkan. Semakin besar bunga yang dibebankan terhadap bunga simpanan maka semakin tinggi pula biaya dananya demikian pula sebaliknya.

2) Biaya operasi

Dalam melakukan setiap kegiatan setiap bank membutuhkan berbagai sarana dan prasarana baik berupa manusia maupun alat. Penggunaan sarana dan prasarana ini memerlukan sejumlah biaya yang harus ditanggung bank sebagai biaya operasi. Biaya operasi merupakan biaya yang dikeluarkan oleh bank dalam melaksanakan operasinya. Biaya ini terdiri dari biaya tenaga kerja, biaya administrasi, biaya pemeliharaan dan biaya-biaya lainnya.

3) Cadangan resiko kredit macet

Merupakan cadangan terhadap macetnya kredit yang akan diberikan, hal ini disebabkan setiap kredit yang diberikan pasti mengandung suatu 
resiko tidak terbayar. Resiko ini dapat timbul baik disengaja maupun tidak disengaja. Oleh karena itu pihak bank perlu mencadangkannya sebagai sikap bersiaga menghadapinya dengan cara membebankan sejumlah presentase tertentu terhadap kredit yang disalurkan.

4) Laba yang diinginkan

Setiap kali melakukan transaksi bank selalu ingin memperoleh laba yang maksimal. Penentuan ini ditentukan oleh beberapa pertimbangan penting, mengingat penentuan besarnya laba sangat mempengaruhi besarnya bunga kredit. Dalam hal ini biasanya bank di samping melihat kondisi pesaing juga melihat kondisi nasabah utama atau bukan dan juga melihat sektor-sektor yang dibiayai.

5) Pajak

Pajak merupakan kewajiban yang dibebankan pemerintah kepada bank yang memberikan fasilitas kredit kepada nasabahnya.

Berdasarkan komponen di atas PT. BPR Berok Gunung Pangilun Padang menetapkan bunga kredit sebesar $19 \%$ pertahun dengan perhitungan sebagai berikut :

Total biaya dana

Total biaya operasi

Cadangan resiko kredit macet

\begin{aligned} 7 & $\% \\ 4 & \% \\$\hline 11 & $\% \\ 2 & \% \\$\hline 13 & $\% \\ 5 & \% \\$\hline 18 & $\% \\ 1 & \% \\$\hline 19 & $\%\end{aligned}$

Pajak 20\% dari laba (5\%)

Bunga Kredit yang diberikan

Sedangkan penentuan suku bunga simpanan terdapat beberapa faktor yang ikut berpengaruh, yaitu :

1) Suku bunga yang dibayarkan kepada deposan berkaitan dengan simpanannya atau suku bunga nominal.

2) Biaya cadangan wajib likuiditas

3) Biaya pelayanan yang termasuk biaya person el dan biaya "overhead"

4) Marjin keuntungan termasuk target penghasilan dari sumber dana di pasar.

5) Tingkat persaingan dan karakteristik deposan.

Sehingga PT. BPR Berok Gunung Pangilun Padang menetapkan bunga tabungan sebesar 5\%-7\% pertahun dan deposito sebesar 7\%-12\% pertahun.

c. Strategi Lokasi

Lokasi bank yang strategis ditujukan agar nasabah mudah menjangkau setiap lokasi bank yang ada. Dalam hal ini penentuan lokasi pada PT. BPR Berok Gunung Pangilun Padang yaitu melalui kantorkantor pelayanan PT. BPR Berok Gunung Pangilun Padang baik itu kantor pusat, kantor pelayanan kas maupun melalui mobil dan sepeda motor unit yang ada di PT. BPR Berok Gunung Pangilun Padang. Penggunaan kantor pelayanan kas membantu bank untuk mencapai sasaran sekaligus meningkatkan pangsa pasarnya. Selain itu juga lebih 
mudah untuk memasarkan produk dan jasa yang ditawarkan oleh bank. Dengan demikian, kantor pelayanan kas merupakan jembatan yang menghubungkan bank dengan nasabah.

PT. BPR Berok Gunung Pangilun mempertimbangkan penentuan lokasi yang dekat dengan pasar seperti :

1) Kantor pusat yang berada di pasar alai

2) Kantor Kas Siteba di pasar siteba

3) Kantor Kas Bandar Buat di pasar bandar buat

4) Kantor kas Pasar Raya di pasar raya

Hal in bertujuan agar nasabah mudah menjangkau setiap lokasi bank yang ada dan bank juga melihat adanya prospek yang potencial yaitu banyaknya pedagang-pedagang, masyarakat yang berada disekitar lokasi pasar tersebut. Sehingga dapat menarik minat calon nasabah yang baru atau dapat mempertahankan nasabah yang sudah ada sekatang ini.

Strategi lokasi yang digunakan oleh PT. BPR Berok Gunung Pangilun adalah dengan menggunakan jaringan kerja yang luas denga cara mendirikan kantor-kantor pelayanan kas. Strategi ini bertujuan untuk mendapatkan nasabah dalam jumlah yang banyak, terutama nasabah yang potensial. Perkembangan jaringan kerja (kantor) PT. BPR Berok Gunung Pangilun dapat dilihat pada tabel berikut ini :

Tabel 3

Perkembangan Jumlah Kantor PT. BPR Berok Gunung Pangilun Tahun 2006-2010

\begin{tabular}{|l|l|l|l|l|l|}
\hline \multicolumn{1}{|c|}{ Jenis Kantor } & $\mathbf{2 0 0 6}$ & $\mathbf{2 0 0 7}$ & $\mathbf{2 0 0 8}$ & $\mathbf{2 0 0 9}$ & $\mathbf{2 0 1 0}$ \\
\hline Kantor Pusat & 1 & 1 & 1 & 1 & 1 \\
Kantor Kas & 3 & 3 & 3 & 3 & 3 \\
Jumlah Kantor & 4 & 4 & 4 & 4 & 4 \\
\hline
\end{tabular}

Sumber : PT. BPR Berok Gunung Pangilun Padang

Saluran dan strategi lokasi yang ditetapkan oleh PT. BPR Berok Gunung Pangilun Padang dalam mencapai sasarannya sehubungan dengan penghimpunan dana masyarakat adalah sebagai berikut :

1) Kantor Pusat dan Pelayanan Kas

Strategi yang digunakan adalah :

a) Melakukan pendekatan/kunjungan kepada pengusaha kecil dan mikro untuk mengembangkan usaha dan pemberian jasa bank.

b) Melakukan pendekatan kepada pedagang-pedagang.

c) Melakukan pendekatan-pendekatan kepada para pegawai negeri dan swasta.

2) Mobil Unit dan Sepeda Motor Unit

Strategi yang digunakan antara lain :

a) Mendatangi pasar-pasar secara rutin dan teratur

b) Mendatangi nasabah tabungan atau mencari nasabah baru yang berada disekitar kota Padang.

c) Menjemput setoran-setoran ke lokasi nasabah.

d) Melihat dan meninjau usaha nasabah yang akan diberikan kredit. 


\section{d. Strategi Promosi}

Promosi merupakan sarana yang paling ampuh untuk menarik dan mempertahankan nasabah. Salah satu tujuan promosi bank adalah menginformasikan segala jenis produk yang ditawarkan dan berusaha menarik calon nasabah yang baru. Adapun bentuk promosi yang telah dilakukan oleh PT. BPR Berok Gunung Pangilun dalam usaha memperkenalkan produk kepada masyarakat adalah :

1) Periklanan

Periklanan yang telah dilakukan PT. BPR Berok Gunung Pangilun adalah dengan menayangkan iklannya melalui surat kabar Singgalang dan Padang Ekspres, radio RRI, pemasangan papan-papan reklame dan spanduk serta pemberian brosur-brosur kepada masyarakat.

2) Kegiatan Promosi Penjualan

Promosi penjualan langsung dilaksanakan oleh PT. BPR Berok Gunung Pangilun kepada masyarakat sehingga masyarakat merasa tertarik untuk menabung di bank tersebut. Misalnya dengan menjemput tabungan ketempat nasabah, memberikan sumbangansumbangan atas kegiatan yang dikoordinir oleh Pemerintah daerah.

3) Publisitas

Kegiatan publisitas dimaksudkan untuk menjaga hubungan baik dengan seluruh masyarakat yang berada dalam wilayah operasional bank. Kegiatan yang telah dilakukan antara lain ikut berpartisipasi dalam kegiatan sosial dan kemasyarakatan seperti menggalakkan program K.3, memberikan sumbangan-sumbangan dan kegiatan sosial lainnya serta memberikan keterangan-keterangan di media massa tentang gambaran umum PT. BPR Berok Gunung Pangilun sekarang dan di masa yang akan datang.

4) Penjualan Pribadi

Kegiatan penjualan pribadi ini secara khusus dilaksanakan oleh petugas yang disebut Customer Service (CS). Karyawan bank dari satpam sampai pimpinan bank harus mampu menjelaskan segala sesuatunya tentang produk dan yang lainnya bbila diperlukan oleh nasabah atau calon nasabah. Bank juga menugaskan karyawan secara langsung untuk mendatangi calon-calon nasabah poensial dan memberikan keterangan yang diperlukan untuk penghimpunan dana dan pemberian kredit.

\section{KESIMPULAN}

Dari hasil penelitian dan hasil analisis data dapat diambil kesimpulan sebagai berikut :

1. PT. BPR Berok Gunung Pangilun Padang adalah suatu lembaga keuangan yang bergerak dibidang perbankan. Produk-produk yang dipasarkan dalam rangka kegiatan operasional bank yaitu menghimpun dana dalam bentuk tabungan yang dilakukan dalam sistem menunggu di kantor dan jemput bola, deposito berjangka serta menyalurkan dana dalam bentuk kredit. Adapun macam-macam bentuk produk kredit yang 
disalurkan PT. BPR Berok Gunung Pangilun Padang adalah kredit investasi, kredit modal kerja dan kredit konsumsi.

2. Dalam melakukan proses pemasaran produk PT. BPR Berok Gunung Pangilun Padang menyediakan berbagai ragam produk yang sesuai dengan keinginan dan kebutuhan nasabah. Produk tersebut berupa tabungan dan deposito, untuk mendapatkan produk tabungan dan deposito nasabah datang ke bank dan menyatakan maksudnya untuk membuka rekening tabungan atau deposito baru dengan mengisi permohonan pembukaan tabungan atau deposito dan menyerahkan photo copy KTP atau SIM serta setoran awal.

3. Sedangkan prosedur untuk pemberian kredit, calon debitur harus mengajukan permohonan kredit kepada PT. BPR Berok Gunung Pangilun Padang dengan jaminan kredit berupa kendaraan, sertifikat tanah, hak sewa toko dan SK bagi PNS serta melengkapi dokumen lainnya. Bagi calon debitur yang memenuhi persyaratan, account officer akan mensurvey ke lapangan dan melakukan analisa terhadap prinsip $5 \mathrm{C}$ yang bertujuan untuk memutuskan apakah kredit tersebut ditolak atau disetujui. Apabila kredit disetujui maka pencarian kredit dapat dilakukan dengan membuka rekening tabungan pada PT. BPR Berok Gunung Pangilun Padang.

4. Berdasarkan Perkembangan penghimpunan dana masyarakat pada PT.BPR Berok Gunung Pangilun Padang tersebut dapat disimpulkan bahwa terjadinya peningkatan penghimpunan dana masyarakat sebesar Rp.2.114.553.000 atau $11,75 \%$ pada tahun 2010. Peningkatan ini disebabkan karena tingginya kepercayaan masyarakat kepada PT. BPR Berok Gunung Pangilun Padang sehingga mau menyimpan dananya dalam bentuk tabungan dan deposito.

5. Sedangkan perkembangan jumlah kredit yang dislurkan oleh PT. BPR Berok Gunung Pangilun Padang juga mengalami peningkatan yang cukup berarti. Hal ini terlihat dari kenaikan jumlah kredit yang disalurkan kepada masyarakat tetap meningkat tiap tahunnya dan pertumbuhan terbesar terjadi pada tahun 2007 yaitu sebesar $102 \%$ dengan jumlah kredit sebesar Rp. 13.500.745.000.

6. Aktivitas Pemasaran produk yang dilakukan oleh PT. BPR Berok Gunung Pangilun Padang yaitu melalui strategi produk yang bertujuan untuk memuaskan keinginan nasabahnya sehingga nasabah tersebut merasakan manfaat dan keuntungan jika memakai produk tersebut, strategi harga dengan tingkat buunga pasar dan berdasarkan jumlah saldo nasabah, strategi lokasi dimana PT. BPR Berok Gunung Pangilun mempertimbangkan penentuan lokasi yang dekat dengan pasar, baik untuk kantor pusat maupun untuk kantor pelayanan kas, strategi promosi melalui periklanan, kegiatan promosi penjualan, publisitas dan penjualan pribadi yang berusaha menarik calon nasabah yang baru dan mempertahankan nasabah yang sudah ada. 


\section{DAFTAR PUSTAKA}

Andika, A., \& Susanti, F. (2018). Pengaruh Marketing Mix Terhadap Keputusan Pembelian Parfum di Azzwars Parfum Lubeg Padang. https://doi.org/10.31227/osf.io/upgc3

Arbi, Syarif. Mengenal Bank dan Lembaga Keuangan Non Bank, Jakarta; Djambatan, 2003.

Aziz, N. (2019). Pengaruh Strategi Promosi Terhadap Keputusan Pembelian Yang Dimediasi Oleh Minat Beli Pada Konsumen Restoran KFC Cabang Khatib Sulaiman Padang. https://doi.org/10.17605/OSF.IO/V92TS

Aziz, N. (2019). Analisis Pengaruh Kualitas Produk, Harga, Promosi Terhadap Keputusan Pembelian Air Minum Dalam Kemasan (AMDK) Merek Aicos Produksi Pt. Bumi Sarimas Indonesia. https://doi.org/10.17605/OSF.IO/8XKYB

Aziz, N. (2019). Pengaruh Atribut Produk Terhadap Minat Beli Sepeda Motor Honda Dealer Amanah Lubuk Alung. https://doi.org/10.17605/OSF.IO/BNDAE

Dendrawijaya, Lukman. Manajemen Perbankan, Jakarta; Ghalia Indonesia, 2001.

F., \& Afriyeni, A. (2019). Aktivitas Pemasaran Produk Tabungan Pada PT. Bank Pembangunan Daerah (BPD) Sumatera Barat Cabang Utama Padang. https://doi.org/10.31219/osf.io/tf2bz

Hidayati, R. R., \& Marlius, D. (2018). Aktivitas Promosi Dalam Meningkatkan Dana Pihak Ketiga Pada PT. Bank Perkreditan Rakyat (BPR) Batang Kapas Pesisir Selatan. https://doi.org/10.31227/osf.io/8dgqn

Kasmir. Manajemen Perbankan, Jakarta; PT. Raja Grafindo Persada, 2003.

Marlius, D. (2017). Keputusan Pembelian Berdasarkan Faktor Psikologis Dan Bauran Pemasaran Pada PT. Intercom Mobilindo Padang. Jurnal Pundi. Volume 1. No. 1. Hal. 57-66. https://doi.org/10.31575/jp.v1i1.9

Marlius, D. (2016). Pengaruh Bauran Pemasaran Jasa Terhadap Minat Nasabah Dalam Menabung Pada Bank Nagari Cabang Muaralabuh. https://doi.org/10.31227/osf.io/vdqgx

Mayliza, R. (2019). Pengaruh Kesadaran Merek, Asosiasi Merek Dan Perception Of Quality Terhadap Keputusan Pembelian Hospital Bed Merek Paramout Di PT. Aga Medika Utama Padang (Studi Kasus Rumah Sakit Umum Kota Padang). https://doi.org/10.17605/OSF.IO/VYQ4E 
Meidisa, C., \& Susanti, F. (2019). Pengaruh Preferensi Dan Pengetahuan Produk Terhadap Minat Menabung Masyarakat Pada Bank Nagari Unit Layanan Syariah Cabang Pasar Raya Padang. https://doi.org/10.31227/osf.io/bf7cr

Safitri, R. N., \& Marlius, D. (2017). Penerapan E-Banking Dalam Meningkatkan Jasa Dan Layanan Perbankan Di PT. Bank Rakyat Indonesia Cabang Padang. https://doi.org/10.31227/osf.io/gkv8t

Sinungan, Muchdarsyah. Manajemen Dana Bank, Jakarta; PT. Bumi Aksara, 2000.

Soedrajat, Setyo, Manajemen Pemasaran Jasa Bank, Jakarta : Info Bank, 1995.

Suhardjono, dan Mudrajad Kuncoro. Manajemen Perbankan, Yogyakarta; BPFE Yogyakarta, 2002.

Susanti, F. (2015). Pengaruh Bauran Promosi Terhadap Keputusan Klien Dalam Memilih Radio Carano Sebagai Media Promosi Iklan. https://doi.org/10.31227/osf.io/b9ws7

Susanti, F. (2014). Pengaruh Tarif Iklan Terhadap Pendapatan Pada PT. Radio Swara Carano Batirai Indah Batusangkar. https://doi.org/10.31227/osf.io/dy863

Susanti, F., \& Gunawan, A. C. (2019). Pengaruh Bauran Promosi Dan Harga Terhadap Keputusan Pembelian Produk Kosmetik Maybelline Di Kota Padang. https://doi.org/10.31227/osf.io/npjqh

Umar, Husein, Research Methods in Finance and Banking, Jakarta; PT. Gramedia Pustaka Utama, 2000.

UU RI No. 10 Tahun 1998. Tentang Perbankan, Jakarta; Sinar Grafika, 1992

Warjiyo, Perry. Bank Sentral RI Sebuah Pengantar, Jakarta; Pusat Pendidikan dan Studi Kebansentralan BI, 2004.

Widayati, R. (2019). Promotional Activities And Services Bank Nagari Kambang Increase In Customer. https://doi.org/10.17605/OSF.IO/MYAVT

Widayati, R. (2019). Aktivitas Pemasaran Produk Simpanan PT. Bank Tabungan Negara (Persero)Tbk Kantor Cabang Padang. https://doi.org/10.17605/OSF.IO/3Z5YC 
Widayati, R. (2019). Aktivitas Pemasaran Produk Tabungan Pada PT. Bpr Rangkiang Denai Payakumbuh Barat. https://doi.org/10.17605/OSF.IO/S3UZM

Wirasasmita, Rivai dan Hadiwidjaja. Analisis Kredit, Bandung; Pionir Jaya, 2000. 